\title{
Black oat (Avena strigosa Schreb.) grazing or silage for small-scale dairy systems in the highlands of central Mexico. Part II. Fatty acid profile of feed and milk
}

\author{
Jesús I. Vega-García ${ }^{1}$, Ernesto Morales-Almaraz ${ }^{2}$, Felipe López-González ${ }^{1}$, Julieta G. Estrada-Flores ${ }^{1}$, \\ and Carlos M. Arriaga-Jordán ${ }^{1 *}$
}

\begin{abstract}
${ }^{1}$ Universidad Autónoma del Estado de México, Instituto de Ciencias Agropecuarias y Rurales (ICAR), Campus UAEM El Cerrillo, CP 50090 Toluca, Estado de México, México. "Corresponding author (cmarriagaj@uaemex.mx).

${ }^{2}$ Universidad Autónoma del Estado de México, Facultad de Medicina Veterinaria y Zootecnia, Campus UAEM El Cerrillo, CP 50090, Toluca, Estado de México, México.
\end{abstract}

Received: 22 November 2019; Accepted: 6 June 2020; doi:10.4067/S0718-58392020000400526

\begin{abstract}
There is growing interest for health attributes in foods, and milk contains polyunsaturated fatty acids (PUFA) beneficial for human health, being forages a main source for dairy cows. This research addressed the hypothesis that black oat (Avena strigosa Schreb.), either grazing regrowth or as first-cut silage in the dry season, is a forage option for small-scale dairy farmers in the central highlands of Mexico. This study presents fatty acid profile of feeds and milk. In Experiment 1 cows grazed for $8 \mathrm{~h} \mathrm{~d}^{-1}$ black oat regrowth (BKO), black oat associated with red clover (BKC) or a multi-species pasture (MSP) of perennial ryegrass, festulolium, and white clover as treatments, and in Experiment 2 treatments were 2.5 (T1), 5.0 (T2) or 7.5 (T3) kg DM cow ${ }^{-1} \mathrm{~d}^{-1}$ of black oat silage (BOS) as complement to grazing. Nine Holstein cows were used in both experiments, in groups of three randomly allotted to treatment sequence in a $3 \times 3$ Latin square design replicated three times. Cows also received $4.6 \mathrm{~kg} \mathrm{DM} \mathrm{d}^{-1}$ commercial concentrate. In Experiment 1 there were significant differences

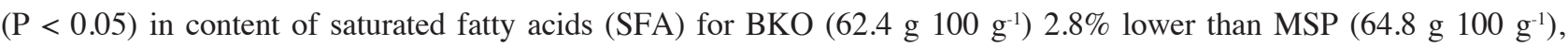

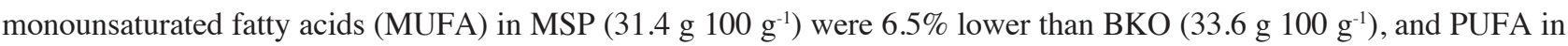

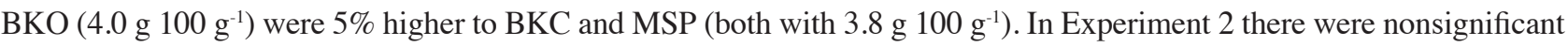
differences $(\mathrm{P}>0.05)$ between treatments in fatty acid groups. Grazing black oat regrowth resulted in milk with higher PUFA contents compared to multispecies pasture representing more benefit for health; but no effect with ensiled black oat.
\end{abstract}

Key words: Alternative forage, CLA, grazing, PUFA, silage.

\section{INTRODUCTION}

Small-scale dairy systems contribute to rural development improving agricultural productivity, incomes for farming families, and contribute to economic growth (Posadas-Domínguez et al., 2014). The profitability and sustainability of these systems requires an optimal use of home-grown forages to reduce reliance on external inputs (Prospero-Bernal et al., 2017).

Grazing is the least expensive feeding strategy for ruminant systems, so that farmers seek to extend grazing seasons which is unfeasible in areas with marked dry seasons that limit herbage growth. Therefore, there is a need in for complementary forages that ensure the quantity and quality of nutrients for milking cows (Morales et al., 2014). 
Black oat (Avena strigosa Schreb.) is a promising small-grain forage with high tillering and regrowth capabilities, good nutritional quality, and high forage production that can be used for grazing or silage.

People are everyday more concerned with the effects on their health of fats from livestock in their diet (Radonjic et al., 2019), and there is also an increasing worldwide interest for foods with attributes that benefit health (Rojas-Rivas et al., 2019); like in milk where polyunsaturated fatty acids (PUFA), and particularly those like conjugated linoleic acid (18:2c9t11; CLA), and vaccenic acid (C18:1t11, a precursor of CLA) are beneficial for human health (Nantapo et al., 2014; Freitas et al., 2019).

Forages are the main source of PUFA for dairy cattle (Khan et al., 2015). Milk contains 70\%-75\% saturated fatty acids (SFA) related hypercholesterolemia and heart disease, 5\% are PUFA as linoleic acid (C18:2) which reduce cholesterol in humans, and the C18:2c9t11 isomer of CLA has shown anti-carcinogenic effects (Nantapo et al., 2014; Prado et al., 2016).

CLA intake in humans is from milk and meat from ruminants and the C18 cis-9, trans-11 isomers from CLA (active component for anti-carcinogenic properties) represents 90\% of total CLA in milk fat (Lock and Garnsworthy, 2002).

Due to the high content of alpha-linolenic acid (C18:3 n3) in green herbage, milk from grazing cows is high in CLA (Morales-Almaráz et al., 2011; Khan et al., 2015; Vicente et al., 2017). Due to the biohydrogenation process, rumenic acid (18:2c9t11), the main isomer of CLA in milk fat, and vaccenic acid (C18:1t11, a precursor of CLA) acids are synthesized in the rumen, so are unique to ruminant fats (Elgersma et al., 2006; Buccioni et al., 2012). Another path for rumenic acid is synthesis in the mammary gland by the $\Delta 9$ desaturase enzyme from vaccenic acid, which accounts for up to $80 \%$ of this isomer in milk (Lock and Garnsworthy, 2002; Bell and Kennelly, 2003).

Lipid profile in milk is due to diet (grazing, silage, concentrate, grain source, and supplemental oils), breed, lactation stage and number, and season of the year (Bergamaschi and Bittante, 2017). Since diet composition enables certain specific fatty acids in milk of ruminants, there is a growing interest in the manipulation of feeding strategies to enhance beneficial fatty acids in milk (Freitas et al., 2019). For example, milk from grazing cows has higher concentrations of polyunsaturated fatty acids (PUFA) and mono unsaturated fatty acids (MUFA), and lower concentrations of saturated fatty acids (SFA) than in milk from cows with diets high in concentrates and conserved forages (Radonjic et al., 2019).

The objective of the work was to determine the fatty acid profile of feeds and milk from two experiments with black oat (Avena strigosa), either grazing regrowth or as first-cut silage in the dry season; as the second part of a study on black oat as a viable forage option for milking cows in small-scale dairy farms in the central highlands of Mexico.

\section{MATERIALS AND METHODS}

Two on farm experiments followed a participatory livestock research approach (Conroy, 2005); on the small-scale dairy farms of four brothers who manage their herds separately but jointly manage their land. The farms are located in the municipality of Aculco in the central highlands of Mexico located at México $20^{\circ} 10^{\prime} \mathrm{N}, 99^{\circ} 48^{\prime} \mathrm{W}$. The area has a subhumid temperate climate at an altitude of $2470 \mathrm{~m}$, mean temperature of $14^{\circ} \mathrm{C}$ and $800 \mathrm{~mm}$ of annual rainfall with a rainy season from May to October and a marked dry season from November to April (Burbano-Muñoz et al., 2018).

Experiment 1 was carried out in Autumn 2016 at the end of the rainy season (10 October to 20 November), and Experiment 2 in Spring 2017 during the dry season (10 April to 21 May).

The two experiments were designed as multiple $3 \times 3$ Latin squares repeated three times (Kaps and Lamberson, 2004; Lawal, 2014) undertaken with nine cows each have been described. Nine lactating Holstein cows were used in both experiments, organized in groups of three (squares) based on parity, days in milk, live weight and milk yield before the experiments (Morales et al., 2014).

Before Experiment 1, cows had a mean milk yield of $11.4 \pm 1.86 \mathrm{~kg} \mathrm{cow}^{-1} \mathrm{~d}^{-1}, 226 \pm 43.2$ days in milk, $502 \pm 22.8 \mathrm{~kg}$ live weight, and $2.4 \pm 0.05$ body condition score (BCS) in a 1 to 5 scale. Prior to Experiment 2, pre-experimental milk yield was $13.4 \pm 1.16 \mathrm{~kg} \mathrm{cow}^{-1} \mathrm{~d}^{-1}, 87 \pm 22.0$ days in milk, $471 \pm 14.31 \mathrm{~kg}$ live weight, and $2.5 \mathrm{BCS}$.

Black oat (Avena strigosa Schreb., 'Saia') was sown on 7 July 2016 at $120 \mathrm{~kg}$ seed ha ${ }^{-1}$ on a 2.5 ha plot, and first growth ensiled at $67 \mathrm{~d}$ post-sowing to be used in Experiment 2. Half the field (1.25 ha) was oversown with $10 \mathrm{~kg} \mathrm{seed} \mathrm{ha}^{-1}$ red clover (Trifolium pratense L., 'Kenland'). At the time of ensiling red clover had not developed so that it was absent in the silage. The regrowth after ensiling was grazed for Experiment 1. 
Multispecies pastures were sown in 2015 with perennial ryegrass (Lolium perenne L., 'Bargala' and 'Payday') and festulolium (Lolium perenne/L. multiflorum $\times$ Festuca pratensis Huds., 'SpringGreen') at a sowing rate of $30 \mathrm{~kg} \mathrm{ha}^{-1}$, associated with white clover (Trifolium repens L., 'Ladino') at $3 \mathrm{~kg}$ seed $\mathrm{ha}^{-1}$.

Experiment 1 evaluated three continuous grazing treatments: grazing of black oat regrowth (BKO), grazing of black oat regrowth associated with red clover (BKC), and grazing of multispecies pasture of temperate grasses and white clover (MSP). Grazing was for $8 \mathrm{~h} \mathrm{~d}^{-1}$ (9:00 to 17:00 h), with water freely available at all times. BKO and BKC plots were adjusted to 1.0 ha, and cows kept overnight in pens after the evening milking with no other feed provided.

Each cow received additionally $4.6 \mathrm{~kg} \mathrm{DM} \mathrm{d}^{-1}$ of a commercial concentrate (21\% crude protein, $\mathrm{CP}$ ) as is customary practice by participating farmers. Concentrate was provided in two split meals a day at milking. Milking was twice a day by hand.

Experiment 2 evaluated the inclusion of three levels of black oat silage (BOS) to complement cows grazing multispecies pastures for $8 \mathrm{~h} \mathrm{~d}^{-1}$ in the dry season.

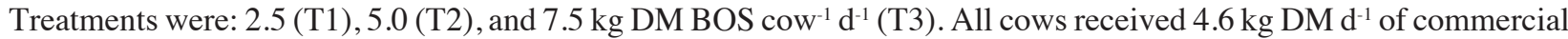
concentrate. Grazing was for $8 \mathrm{~h} \mathrm{~d}^{-1}$ (09:00 to 17:00 h).

The BOS and concentrate, weighed daily for each cow, were individually provided per cow, divided in two equal meals in the overnight pen after milking. BOS refusals were weighed every morning, with no refusals for concentrate. Drinking water was available at all times for cows at pasture and in the overnight pens.

Stocking rate in both experiments was 3 cows ha- ${ }^{-1}$, and both experiments had three experimental periods of $14 \mathrm{~d}$ duration each, with $10 \mathrm{~d}$ for adaptation to diets and $4 \mathrm{~d}$ for sampling and measurements following Pérez-Prieto et al. (2012).

\section{Fatty acid profiles of feeds and milk}

Composite samples of hand-plucked herbage simulating grazing from pastures, and from different areas in the silos, as well as from concentrate, from each experimental period were analyzed for fatty acids.

Fatty acid profiles were determined following Vieyra-Alberto et al. (2017) and Plata-Reyes et al. (2018). Methods were described by Sukhija and Palmquist (1988), modified by Palmquist and Jenkins (2003), using 10\% methanolic hydrochloric acid for esterification, and hexane as organic solvent.

Milk fat was extracted and methylated by methods described by Christie (1982), modified by Chouinard et al. (1999). Separation and determination of methyl esters of fatty acids of herbage, commercial concentrate and milk was by gas chromatography (Clarus 500, Perkin Elmer, Waltham, Massachusetts, USA), with a capillary column $100 \mathrm{~m} \times 0.25 \mathrm{~mm}$ $\times 0.2 \mu \mathrm{m}$ (SP-2560, Supelco, Bellefonte, Pennsylvania, USA), with nitrogen as carrier gas (Plata-Reyes et al., 2018).

Both the detector and injector were held at $260{ }^{\circ} \mathrm{C}$, with the initial temperature of the furnace at $140{ }^{\circ} \mathrm{C}$ for $5 \mathrm{~min}$ increasing $4{ }^{\circ} \mathrm{C}$ per minute till achieving $240{ }^{\circ} \mathrm{C}$ (Vieyra-Alberto et al., 2017). Identification of individual fatty acid peaks

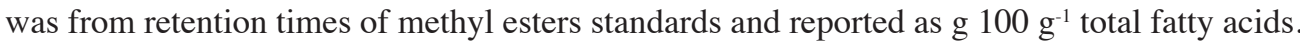

Results obtained were for saturated fatty acids (SFA), monounsaturated fatty acids (MFA), polyunsaturated fatty acids, omega-3 (n-3) fatty acids, omega-6 (n-6) fatty acids, the n-6/n-3 ratio following Nantapo et al. (2014). Calculation of the atherogenic index was from the equation by Ulbricht and Southgate (1991), derived from the ratio of SFA/total fatty acids:

Atherogenic index $=[\mathrm{C} 12: 0+4(\mathrm{C} 14: 0)+(\mathrm{C} 16: 0)] / \Sigma(\mathrm{MUFA}+\mathrm{PUFA})$

Statistical analyses of results for individual fatty acid contents in milk fat for both experiments were with ANOVA within a multiple $3 \times 3$ Latin square design repeated three times, simultaneous in space and time (Kaps and Lamberson, 2004; Lawal, 2014) with the following model (Plata-Reyes et al., 2018):

$$
\mathrm{Y}_{\mathrm{ijk} \mathrm{l}}=\mu+\mathrm{S}_{\mathrm{i}}+\mathrm{C}_{\mathrm{j}(\mathrm{i})}+\mathrm{P}_{\mathrm{k}}+\mathrm{t}_{\mathrm{l}}+\mathrm{e}_{\mathrm{ijkl}}
$$

where $\mu$ is general mean, $\mathrm{S}$ is the effect due the $\mathrm{i}^{\text {th }}$ Latin square $(1,2,3), \mathrm{C}$ is the effect due to $\mathrm{j}^{\text {th }}$ cow $(1,2,3)$ within each square, $\mathrm{P}$ is the effect due to the $\mathrm{k}^{\text {th }}$ experimental period $(1,2,3)$, $\mathrm{t}$ is the effect due to $\mathrm{l}^{\text {th }}$ treatment $(1,2,3)$, and $\mathrm{e}$ is residual error term.

The work herein reported is from an on farm experiment undertaken with four participating farmers who had knowledge of the objectives of the work and were duly informed at all times, and their privacy and that of their family is respected by not disclosing their names. Experimental procedures with dairy cows, and research with collaborating farmers followed accepted procedures by Universidad Autónoma del Estado de México. 


\section{RESULTS}

Fatty acid profile of feeds

Fresh green forage and herbage in the three treatments (BKO, BKC, and MSP) were a good source of unsaturated fatty acids (70\% total fatty acids). There were less unsaturated fatty acids in BOS in Experiment 2 than on fresh black oat forage in Experiment 1 (Table 1). Both in pastures as in the black oat crops, linoleic acid was the predominant fatty acid.

\section{Fatty acid profile of milk fat}

Table 2 shows results for fatty acids in milk from both experiments. In Experiment 1, there were significant difference $(\mathrm{P}<0.05)$ between treatments for palmitic acid $(\mathrm{C} 16: 0)$ with higher values in BKO than in BKC and MSP; and for oleic acid (C18:1c9) with higher values in BKO and lower in MSP, with BKC intermediate. The same was observed for other fatty acids.

There were significant differences for SFA $(\mathrm{P}<0.05)$ with BKO having lower values, as well as for MUFA and PUFA, with BKO obtaining higher values than MSP with BKC intermediate. There were no differences $(\mathrm{P}>0.05)$ for $\mathrm{n}-6$, but a trend was observed $(\mathrm{P}<0.06)$ for $\mathrm{n}-3$, with $\mathrm{BKO}$ having the highest values.

These figures resulted in a significantly $(\mathrm{P}<0.05)$ lower ratio of $n-6 / n-3$ for BKO and atherogenic index, although in the three treatments results were satisfactory since the index was only 2.0 in BKC and MSP.

Table 1. Fatty acid profile of feeds in Experiment 1 and Experiment 2.

\begin{tabular}{|c|c|c|c|c|}
\hline \multirow[b]{2}{*}{ Experiment 1} & \multicolumn{4}{|c|}{ Treatments } \\
\hline & BKO & $\mathrm{BKC}$ & MSP & Concentrate \\
\hline & & - & & + \\
\hline Butyric (C4:0) & 0.3 & - & 1.1 & 0.2 \\
\hline Lauric (C12:0) & 0.7 & 0.7 & 1.2 & 0.2 \\
\hline Tridecanoic (C13:0) & 2.6 & 2.3 & 1.5 & - \\
\hline Myristic (C14:0) & 0.7 & 0.6 & 0.8 & 0.3 \\
\hline cis-10 Pentadecanoic (C15:1) & 1.3 & 1.2 & 1.8 & - \\
\hline Palmitic (C16:0) & 19.0 & 18.2 & 19.7 & 22.1 \\
\hline Palmitoleic (C16:1) & 1.7 & 1.9 & 1.4 & 0.3 \\
\hline Stearic $(\mathrm{C} 18: 0)$ & 2.8 & 2.3 & 2.1 & 2.2 \\
\hline Oleic (C18:1c9) & 2.6 & 2.4 & 1.7 & 1.5 \\
\hline Linoleic (C18:2n6c) & 10.9 & 13.4 & 11.7 & 29.1 \\
\hline Linolenic (C18:3n3) & 57.4 & 57.0 & 57.0 & 44.1 \\
\hline SFA & 26.1 & 24.1 & 26.4 & 25.0 \\
\hline MUFA & 5.6 & 5.5 & 4.9 & 1.8 \\
\hline PUFA & 68.3 & 70.4 & 68.7 & 73.2 \\
\hline \multirow[t]{2}{*}{ Experiment 2} & $\mathrm{~T} 1$ & $\mathrm{~T} 2$ & $\mathrm{~T} 3$ & Concentrate \\
\hline & \multicolumn{4}{|c|}{ g $100 \mathrm{~g}^{-1}$} \\
\hline Butyric (C4:0) & 1.3 & 1.5 & 0.8 & 3.2 \\
\hline Lauric (C12:0) & 1.2 & 1.1 & 1.4 & 1.7 \\
\hline Tridecanoic (C13:0) & 0.9 & 2.2 & 0.9 & - \\
\hline Myristic (C14:0) & 1.1 & 0.7 & 0.8 & 1.4 \\
\hline cis-10 Pentadecanoic (C15:1) & 1.0 & 2.0 & 1.6 & - \\
\hline Palmitic (C16:0) & 28.7 & 18.5 & 20.8 & 32.9 \\
\hline Palmitoleic (C16:1) & 1.3 & 1.2 & 1.7 & - \\
\hline Stearic $(\mathrm{C} 18: 0)$ & 2.3 & 2.2 & 2.0 & 3.5 \\
\hline Oleic (C18:1c9) & 3.8 & 1.7 & 1.7 & 3.8 \\
\hline Linoleic (C18:2n6c) & 16.0 & 10.1 & 13.2 & 13.0 \\
\hline Linolenic (C18:3n3) & 42.4 & 58.8 & 55.1 & 40.5 \\
\hline SFA & 35.5 & 26.2 & 26.7 & 42.7 \\
\hline MUFA & 6.1 & 4.9 & 5.0 & 3.8 \\
\hline PUFA & 58.4 & 68.9 & 68.3 & 53.5 \\
\hline
\end{tabular}


Table 2. Milk fatty acid profile in Experiment 1 and Experiment 2.

\begin{tabular}{|c|c|c|c|c|c|}
\hline \multirow[b]{2}{*}{ Experiment 1} & \multicolumn{3}{|c|}{ Treatments } & \multirow[b]{2}{*}{ SEM } & \multirow[b]{2}{*}{$P$ value } \\
\hline & $\mathrm{BKO}$ & $\mathrm{BKC}$ & MSP & & \\
\hline & 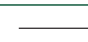 & $100 \mathrm{~g}^{-1}$ & - & & \\
\hline \multicolumn{6}{|l|}{ Short-chain } \\
\hline Butyric (C4:0) & $3.6 \mathrm{~b}$ & $4.0 \mathrm{ab}$ & $4.2 \mathrm{a}$ & 0.152 & 0.013 \\
\hline Caproic (C6:0) & $2.3 b$ & $2.7 \mathrm{a}$ & $2.5 \mathrm{ab}$ & 0.095 & 0.044 \\
\hline Caprylic (C8:0) & 1.2 & 1.3 & 1.1 & 0.053 & 0.109 \\
\hline Capric (C10:0) & 2.2 & 2.4 & 2.1 & 0.104 & 0.136 \\
\hline Undecanoic (C11:0) & 0.2 & 0.2 & 0.2 & 0.021 & 0.112 \\
\hline Lauric $(\mathrm{C} 12: 0)$ & 2.3 & 2.4 & 2.1 & 0.108 & 0.208 \\
\hline \multicolumn{6}{|l|}{ Medium-chain } \\
\hline Myristic (C14:0) & 9.6 & 10.0 & 9.7 & 0.277 & 0.502 \\
\hline Myristoleic (C14:1) & 0.5 & 0.5 & 0.5 & 0.028 & 0.662 \\
\hline Pentadecanoic (C15:0) & 0.9 & 0.9 & 0.7 & 0.080 & 0.234 \\
\hline cis-10-Pentadecanoic (C15:1) & 1.1 & 0.9 & 0.9 & 0.040 & 0.107 \\
\hline Palmitic (C16:0) & $26.2 b$ & $26.7 b$ & $28.5 \mathrm{a}$ & 0.315 & 0.000 \\
\hline Palmitoleic (C16:1) & 2.0 & 1.8 & 1.8 & 0.073 & 0.067 \\
\hline Heptadecanoic (C17:0) & 0.5 & 0.5 & 0.5 & 0.030 & 0.928 \\
\hline cis-10-Heptadecanoic (C17:1) & 0.2 & 0.2 & 0.2 & 0.012 & 0.159 \\
\hline \multicolumn{6}{|l|}{ Long-chain } \\
\hline Stearic (C18:0) & 12.8 & 12.5 & 12.6 & 0.332 & 0.841 \\
\hline Vaccenic (C18:1t11) & 1.7 & 1.7 & 1.7 & 0.065 & 0.879 \\
\hline Oleic (C18:1c9) & $28.0 \mathrm{a}$ & $26.8 \mathrm{ab}$ & $26.3 b$ & 0.402 & 0.011 \\
\hline Linoleic (C18:2n6c) & 1.5 & 1.4 & 1.4 & 0.056 & 0.299 \\
\hline Linolelaidic (C18:2n6t) & 0.1 & 0.1 & 0.1 & 0.009 & 0.059 \\
\hline Linolenic (C18:3n3) & 0.3 & 0.2 & 0.2 & 0.011 & 0.057 \\
\hline Rumenic (C18:2c9t11) & 1.1 & 1.1 & 1.0 & 0.054 & 0.152 \\
\hline Others & $0.9 \mathrm{a}$ & $0.8 \mathrm{ab}$ & $0.8 \mathrm{~b}$ & 0.018 & 0.035 \\
\hline SFA & $62.4 \mathrm{~b}$ & $64.2 \mathrm{a}$ & $64.8 \mathrm{a}$ & 0.449 & 0.000 \\
\hline MUFA & $33.6 \mathrm{a}$ & $32.0 \mathrm{~b}$ & $31.4 \mathrm{~b}$ & 0.441 & 0.003 \\
\hline PUFA & $4.0 \mathrm{a}$ & $3.8 \mathrm{~b}$ & $3.8 \mathrm{~b}$ & 0.077 & 0.012 \\
\hline$n-6$ & 1.7 & 1.6 & 1.5 & 0.059 & 0.202 \\
\hline \multirow[t]{2}{*}{ Experiment 2} & $\mathrm{~T} 1$ & $\mathrm{~T} 2$ & $\mathrm{~T} 3$ & SEM & $P$ value \\
\hline & \multicolumn{3}{|c|}{ 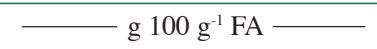 } & & \\
\hline$n-3$ & 0.32 & 0.29 & 0.28 & 0.011 & 0.057 \\
\hline$n-6 / n-3$ & 0.1 & 0.1 & 0.1 & 0.008 & 0.643 \\
\hline Atherogenicity index & $1.8 \mathrm{~b}$ & $2.0 \mathrm{a}$ & $2.0 \mathrm{a}$ & 0.057 & 0.032 \\
\hline \multicolumn{6}{|l|}{ Short-chain } \\
\hline Butyric (C4:0) & 3.9 & 4.1 & 4.2 & 0.128 & 0.093 \\
\hline Caproic (C6:0) & $2.7 \mathrm{~b}$ & $2.9 \mathrm{a}$ & $2.8 \mathrm{ab}$ & 0.062 & 0.011 \\
\hline Caprylic (C8:0) & $1.5 b$ & $1.5 \mathrm{a}$ & $1.5 \mathrm{ab}$ & 0.033 & 0.019 \\
\hline Capric (C10:0) & 3.1 & 3.1 & 3.1 & 0.089 & 0.390 \\
\hline Undecanoic (C11:0) & 0.2 & 0.2 & 0.2 & 0.015 & 0.387 \\
\hline Lauric $(\mathrm{C} 12: 0)$ & 3.3 & 3.1 & 3.3 & 0.095 & 0.513 \\
\hline \multicolumn{6}{|l|}{ Medium-chain } \\
\hline Myristic (C14:0) & 11.9 & 11.6 & 11.9 & 0.208 & 0.338 \\
\hline Myristoleic (C14:1) & 0.5 & 0.5 & 0.5 & 0.021 & 0.847 \\
\hline Pentadecanoic $(\mathrm{C} 15: 0)$ & 0.7 & 0.7 & 0.7 & 0.030 & 0.249 \\
\hline cis-10-Pentadecanoic (C15:1) & 1.0 & 1.0 & 1.0 & 0.026 & 0.938 \\
\hline Palmitic (C16:0) & 28.3 & 27.7 & 28.2 & 0.373 & 0.599 \\
\hline Palmitoleic (C16:1) & 1.4 & 1.3 & 1.3 & 0.039 & 0.460 \\
\hline Heptadecanoic (C17:0) & 0.5 & 0.4 & 0.4 & 0.024 & 0.175 \\
\hline cis-10-Heptadecanoic (C17:1) & $0.2 \mathrm{a}$ & $0.1 \mathrm{~b}$ & $0.1 \mathrm{~b}$ & 0.008 & 0.002 \\
\hline \multicolumn{6}{|l|}{ Long-chain } \\
\hline Stearic $(\mathrm{C} 18: 0)$ & 12.0 & 12.9 & 12.1 & 0.330 & 0.612 \\
\hline Vaccenic (C18:1t11) & 1.6 & 1.7 & 1.7 & 0.062 & 0.665 \\
\hline Oleic (C18:1c9) & 22.6 & 23.0 & 22.3 & 0.445 & 0.093 \\
\hline Linoleic (C18:2n6c) & 1.6 & 1.6 & 1.6 & 0.063 & 0.426 \\
\hline Linolelaidic (C18:2n6t) & 0.1 & 0.1 & 0.1 & 0.007 & 0.798 \\
\hline
\end{tabular}


Continuation Table 2.

\begin{tabular}{|c|c|c|c|c|c|}
\hline \multirow[b]{2}{*}{ Experiment 2} & \multicolumn{3}{|c|}{ Treatments } & \multirow[b]{2}{*}{ SEM } & \multirow[b]{2}{*}{$P$ value } \\
\hline & $\mathrm{T} 1$ & $\mathrm{~T} 2$ & $\mathrm{~T} 3$ & & \\
\hline & \multicolumn{3}{|c|}{${\mathrm{g} 100 \mathrm{~g}^{-1} \mathrm{FA}}$} & & \\
\hline Linolenic (C18:3n3) & 0.3 & 0.3 & 0.3 & 0.014 & 0.177 \\
\hline Rumenic (C18:2c9t11) & 1.0 & 1.0 & 0.9 & 0.044 & 0.891 \\
\hline Others & 0.8 & 0.7 & 0.7 & 0.056 & 0.414 \\
\hline SFA & 68.6 & 68.5 & 69.0 & 0.513 & 0.082 \\
\hline MUFA & 27.2 & 27.6 & 27.0 & 0.457 & 0.099 \\
\hline PUFA & 3.2 & 3.1 & 3.1 & 0.085 & 0.486 \\
\hline$n-6$ & 1.8 & 1.7 & 1.8 & 0.067 & 0.466 \\
\hline$n-3$ & 0.3 & 0.3 & 0.3 & 0.014 & 0.177 \\
\hline$n-6 / n-3$ & 0.1 & 0.1 & 0.1 & 0.010 & 0.708 \\
\hline Atherogenic index & 2.6 & 2.5 & 2.6 & 0.084 & 0.171 \\
\hline
\end{tabular}

Means with different lower-case letters within a row are different according to Tukey test $(\mathrm{P}<0.05)$. BKO: Black oat pasture; BKC: black oat with red clover; MSP: multi-species pasture; SEM: standard error of the mean; T1: $2.5 \mathrm{~kg} \mathrm{DM}$ cow d$^{-1}$ black oat silage (BOS); T2: $5.0 \mathrm{~kg} \mathrm{DM}$ cow d ${ }^{-1}$ BOS; T3: $7.5 \mathrm{~kg}$ DM cow d $\mathrm{d}^{-1}$ BOS; SFA: saturated fatty acids; MUFA: monounsaturated fatty acids; PUFA: polyunsaturated fatty acids.

In Experiment 2 there were significant differences $(\mathrm{P}<0.05)$ for caproic $(\mathrm{C} 6: 0)$, caprylic $(\mathrm{C} 8: 0)$ acids, and cis-10-heptadecenoic.

There were nonsignificant differences in any other of the fatty acids determined, although there was a trend $(\mathrm{P}<0.10)$ for higher oleic acid in T2, and in the SFA and MUFA contents. There were no differences $(\mathrm{P}>0.05)$ in the atherogenic index between treatments.

\section{DISCUSSION}

\section{Fatty acid profile of feeds}

Aspects like plant species and maturity are sources of large variation in the fatty acid contents (Khan et al., 2015). Temperate grasses have more alpha-linolenic acid (C18:3n3) which represent the highest component of the fatty acid profile of pasture plants (Hernández-Ortega et al., 2014), with lower contents of palmitic (C16:0) and linoleic acid (C18:2n6) compared with legumes.

Black oat regrowth in Experiment 1 was a better source of PUFA than the multispecies pasture, which might have been due to a better leaf:stem ratio (41:59).

Fatty acid content is reduced with maturity of plants related with a lower proportion of leaves and the initiation of flowering and leaf senescence causing the degradation of chloroplast membranes with the decrease in lipid and thus fatty acid content (Khan et al., 2015). This holds relevance to the work herein reported as there are no reports in the literature on the fatty acid profile of black oat regrowth.

Alpha-linolenic acid (C18:3 n3) was higher in MSP in Experiment 1, with similar contents for BKO, BKC for C12:0, C13:0, C16:0, C18:2n6c; and lower levels for C14:0, C16:1, C18:0, C18:1c9; when compared to the fatty acid profiles of multiple species pasture evaluated by Castro-Hernández et al. (2014).

In black oat silage (BOS) in Experiment 2, C18:3, C16:0 and C18:2 comprised 90\% of fatty acid content; with 60\% of the total constituted by $\mathrm{C} 18: 2$ and $\mathrm{C} 18: 3$. Both acids are essential for ruminants, are an important presence in their diet as precursors of CLA, that as was mentioned has beneficial effects on human health against carcinogenesis, atherosclerosis, diabetes, and excess body fat (Lock and Garnsworthy, 2002).

\section{Fatty acid profile in milk}

Several authors (Kay et al., 2004; Morales-Almaráz et al., 2011; Vicente et al., 2017; Vieyra-Alberto et al., 2017) have stated that grazing dairy cows have higher intakes of linoleic (C18:2) and linolenic (C18:3) acids compared to confined cows due to the larger intake of these fatty acids from fresh herbage. This increases rumenic (C18:2c9t11) and vaccenic (C18:1t11) acids in milk, such as observed in Experiment 1 in milk, where PUFA content in milk was higher when 
cows grazed the black oat regrowth; with higher levels than reported by Plata-Reyes et al. (2018), who reported a mean

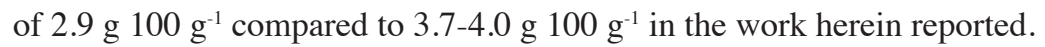

In Experiment 2, using BOS with significantly different intakes from pastures, there were no differences in PUFA contents in milk $(\mathrm{P}>0.05)$ among treatments.

The black oat crop was at the heading stage at the time of cutting for silage. Although working with maize silage, Khan et al. (2011) stated that as plants mature there is a decrease in PUFA content. Although the black oat crop was at a right time for ensiling, the crop may have passed the optimal stage for high PUFA content.

Fatty acids remain stable during ensiling independently of fermentations taking place within, and losses during feeding are limited, so that most losses of PUFA happen between cutting and the end of the aerobic phase during ensiling.

The final transfer of PUFA from the rumen environment to milk depends also of aspects related to individual animals in their metabolism of fatty acids, since lipolysis rates depend on the microbial ecosystem in the rumen, where variations in rumen $\mathrm{pH}$ affect lipase activity that in turns affects biohydrogenation, and the absorption rate increases as the concentration of PUFA increases in the rumen (Doreau and Ferlay, 1994).

Short and medium chain fatty acid content in milk in Experiment 1 were lower than reported by Vargas et al. (2013), who worked with dairy cows grazing subtropical kikuyu grass. In terms of long chain fatty acids, results were variable, but vaccenic acid content (C18:1c9) was higher in the work herein reported.

Saturated capric and stearic fatty acids (C10:0 and C18:0) were higher in Experiment 2 than those reported by Hernández-Ortega et al. (2014) for grazing cows supplemented with maize silage; but similar for lauric acid (C12:0), and lower for myristic (C14:0) and palmitic (C16:0) acids. In terms or PUFA, results were lower for linolenic (C18:2n6c) and rumenic (C18:2c9t11) acids, but similar for linolenic acid (C18:3n3).

The lowest atherogenicity index for Experiment 1 was 1.8, while the highest index in Experiment 2 was 2.6, within the ranges that pose no risk for human health (Ulbricht and Southgate, 1991).

\section{CONCLUSIONS}

Grazing black oat regrowth results in a higher content of polyunsaturated fatty acids beneficial for human health compared to grazing black oat plus red clover regrowth or a temperate grass with white clover pasture.

Different levels of inclusion of black oat silage to dairy cows grazing temperate grasses and white clover pasture did not affect contents of saturated, monounsaturated, and polyunsaturated fatty acids in milk.

\section{ACKNOWLEDGEMENTS}

Authors express gratitude to the farmers who participated in this experiment, whose privacy is respected by not disclosing their names. Appreciation also to Ms. María de Lourdes Maya Salazar and Ms. Laura Edith Martínez Contreras for their assistance in the laboratory. This work was undertaken thanks to funding by the Autonomous University of the State of Mexico (Universidad Autónoma del Estado de México) through grant UAEM 3676/2014/CIA, and the Mexican National Council for Science and Technology (Consejo Nacional de Ciencia y Tecnología, CONACYT) for the postgraduate grant for Jesús Israel Vega-García.

\section{REFERENCES}

Bell, J.A., and Kennelly, J.J. 2003. Short communication: postruminal infusion of conjugated linoleic acids negatively impacts milk synthesis in holstein cows. Journal of Dairy Science 86:1321-1324.

Bergamaschi, M., and Bittante, G. 2017. Detailed fatty acid profile of milk, cheese, ricotta and by products, from cows grazing summer highland pastures. Journal of Dairy Science 84:329-338. doi:10.1017/S0022029917000450.

Buccioni, A.M., Decandia, M., Minieri, S., Molle, G., and Cabiddu A. 2012. Lipid metabolism in the rumen: New insights on lipolysis and bio hydrogenation with an emphasis on the role of endogenous plant factors. Animal Feed Science Technology 174:1-25. doi:10.1016/j.anifeedsci.2012.02.009.

Burbano-Muñoz, V.A., López-González, F., Estrada-Flores, J.G., Sainz-Sánchez, P.A., and Arriaga-Jordán, C.M. 2018. Oat silage for grazing dairy cows in small scale dairy Systems in the highlands of central Mexico. African Journal of Range and Forage Science 35:63-70. doi:10.2989/10220119.2018.1473493. 
Castro-Hernández, H., González Martínez, F.F., Domínguez-Bara, I.A., Pinos-Rodríguez, J.M., Morales-Almaraz, E., y VieyraAlberto, R. 2014. Efecto del nivel de concentrado sobre el perfil de ácidos grasos de la leche de vacas Holstein en pastoreo. Agrociencia 48:765-775.

Chouinard, P.Y., Corneau, L., Barbano, D.M., Metzger, L.E., and Bauman, D.E. 1999. Conjugated linoleic acids alter milk fatty acid composition and inhibit milk fat secretion in dairy cows. The Journal of Nutrition 129:1579-1584. doi:10.1093/jn/129.8.1579.

Christie, W.W. 1982. A simple procedure for rapid transmethylation of glycerolipids and cholesteryl esters. The Journal of Lipid Research 23:1072-1075.

Conroy, C. 2005. Participatory livestock research. ITDG Publishing, Bourton-on-Dunsmore, Warwickshire, UK.

Doreau, M., and Ferlay, A. 1994. Digestion and utilization of fatty acids by ruminants. Animal Feed Science and Technology 45:379-396. doi:10.1016/0377-8401(94)90039-6.

Elgersma, A., Tamminga, S., and Ellen, G. 2006. Modifying milk composition through forage. Animal Feed Science and Technology 131:207-225. doi:10.1002/ejlt.201400469.

Freitas, W.R., Gama, M.A.S., Silva, J.L., Véras, A.S.C., Chagas, J.C.C., Conceicao, M.G., et al. 2019. Milk fatty acid profile of dairy cows fed diets based on sugarcane bagasse in the Brazilian semiarid region. Chilean Journal of Agricultural Research 79:464-472. doi:10.4067/S0718-58392019000300464

Hernández-Ortega, M., Martínez-Fernández, A., Soldado, A., González, A., Arriaga-Jordán, C.M., Argamentería, A., et al . 2014. Effect of total mixed ration composition and daily grazing pattern on milk production, composition and fatty acids profile of dairy cows. Journal of Dairy Research 81:471-478. doi:10.1017/S0022029914000399.

Kaps, M., and Lamberson, W. R. 2004. Change-over designs. p. 294-312. In Kaps, M., and Lamberson, W. (eds.) Biostatistics for animal science. Cromwell Press, Trowbridge, UK.

Kay, J.K., Mackle, T.R., Auldist, M.J., Thompson, N.A., and Bauman, D.E. 2004. Endogenous synthesis of cis-9, trans-11, conjugated linoleic acid in dairy cows fed fresh pasture. Journal of Dairy Science 87:369-378.

Khan, N.A., Cone, J.W., Pellikaan, W.F., Khan, M.A., Struik, P.C., and Hendriks, W.H. 2011. Changes in fatty acid content and composition in silage maize during grain filling. Journal of the Science of Food and Agriculture 91:10411049. doi:10.1002/jsfa.4279.

Khan, N.A., Farooq, M.W., Ali, M., Suleman, M., Ahmad, N., Sulaiman, S.M., et al. 2015. Effect of species and harvest maturity on the fatty acids profile of tropical forages. The Journal of Animal and Plant Sciences 25:739-746.

Lawal, B. 2014. Applied statistical methods in agriculture, health and life sciences. Springer, Cham, Switzerland.

Lock, A.L., and Garnsworthy, P.C. 2002. Independent effects of dietary linoleic and linolenic fatty acids on the conjugated linoleic acid content of cows' milk. Animal Science 74:163-176.

Morales, A., Grob, D., Balocchi, O., and Pulido, R. 2014. Productive and metabolic response to two levels of corn silage supplementation in grazing dairy cows in early lactation during autumn. Chilean Journal of Agricultural Research 74:205212. doi:10.4067/S0718-58392014000200012.

Morales-Almaráz, E., De la Roza-Delgado, B., González, A., Soldado, A., Rodríguez, M.L., Peláez, M., et al. 2011. Effect of feeding system on unsaturated fatty acid level in milk of dairy cows. Renewable Agriculture and Food Systems 26:224-229. doi:10.1017/S1742170511000019.

Nantapo, C.T.W., Muchenje, V., and Hugo, A. 2014. Atherogenicity index and health-related fatty acids in different stages of lactation from Friesian, Jersey and Friesian $\times$ Jersey cross cow milk under a pasture-based dairy system. Food Chemistry 146:127-133. doi:10.1016/j.foodchem.2013.09.009.

Palmquist, D.L., and Jenkins, T.C. 2003. Challenges with fats and fatty acids methods. Journal of Animal Science 81:32503254. doi:10.2527/2003.81123250x.

Pérez-Prieto, L.A., Peyraud, J.L., and Delagarde, R. 2012. Does pre-grazing herbage mass really affect herbage intake and milk production of strip-grazing dairy cows? Grass and Forage Science 68:93-109. doi:10.1111/j.1365-2494.2012.00876.x.

Plata-Reyes, D.A., Morales-Almaraz, E., Martínez-García, C.G., Flores-Calvete, G., López-González, F., PrósperoBernal, F., et al. 2018. Milk production and fatty acid profile of dairy cows grazing four grass species pastures during the rainy season in small-scale dairy Systems in the highlands of Mexico. Tropical Animal Health and Production 50:1797-1805. doi:10.1007/s11250-018-1621-8.

Posadas-Domínguez, R.R., Arriaga-Jordán, C.M., and Martínez-Castañeda, F.E. 2014. Contribution of family labour to the profitability and competitiveness of small-scale dairy production systems in Central Mexico. Tropical Animal Health and Production 46:235-240. doi:10.1007/s11250-013-0482-4.

Prado, R.M., Palin, M.F., Prado, I.N., Dos Santos, G.T., Benchaar, C., and Petit, H.V. 2016. Milk yield composition and hepatic lipid metabolism in transition dairy cows fed flaxseed or linola. Journal of Dairy Science 99:1-16. doi:10.3168/jds.2016-11003.

Prospero-Bernal, F., Martínez-García, C.G., Olea-Pérez, R., López-González, F., and Arriaga-Jordán, C.M. 2017. Intensive grazing and maize silage to enhance the sustainability of small-scale dairy systems in the highlands of Mexico. Tropical Animal Health and Production 49:1537-1544. doi:10.1007/s11250-017-1360-2. 
Radonjic, D., Djordjevic, N., Markovic B., Markovic, M., Stesevic, D., and Dajic-Stevanovic, Z. 2019. Effect of phenological phase of dry grazing pasture on fatty acid composition of cows' milk. Chilean Journal of Agricultural Research 79:278-287. doi:10.4067/S0718-58392019000200278.

Rojas-Rivas, E., Espinoza-Ortega, A., Thomé-Ortiz, H., and Moctezuma-Pérez, S. 2019. Consumers' perception of amaranth in Mexico. British Food Journal 121:1190-1202. doi:10.1108/BFJ-05-2018-0334.

Sukhija, P.S., and Palmquist, D.L. 1988. Rapid method for determination of total fatty acid content and composition of feedstuffs and feces. Journal of Agricultural and Food Chemistry 36:1202-1206. doi:10.1021/jf00084a019.

Ulbricht, T.L.V., and Southgate, D.A.T. 1991. Coronary heart disease: Seven dietary factors. The Lancet 338:985-992.

Vargas, M.J., Mojica, R.J., Pabón, R.M., y Carulla, F.J. 2013. Oferta de pasto kikuyo (Pennisetum clandestinum), tercio de lactancia y perfil de ácidos grasos lácteos. Revista MVZ Córdoba 18:3681-3688.

Vicente, F., Santiago, C., Jiménez-Calderón, J.D., and Martínez-Fernández, A. 2017. Capacity of milk composition to identify the feeding system used to feed dairy cows. Journal of Dairy Research 84:254-263. doi:10.1017/S0022029917000383.

Vieyra-Alberto, R., Arriaga-Jordán, C.M., Domínguez-Vara, I.A., Bórquez-Gastelum, J.L., y Morales-Almaráz, E. 2017. Efecto del aceite de soya sobre la concentración de los ácidos grasos vaccénico y ruménico en leche de vacas en pastoreo. Agrociencia 51:299-313. 